\title{
Phenomenon of interaction between the solder melts on the basis of copper and the steel detail surface
}

\section{Oddziaływanie ciekłego lutu na osnowie miedzi na granicy z podłożem stalowym}

\section{Abstract}

The article is devoted to problems in interaction between steel surface actually stainless steel one and the melt of copper based alloys. Conditions of base material properties decreasing have been determined including well-known effect of brittleness under the melt action. Authors studied effect of penetration of copper along the borders of steel grains. Possibility of stainless steel brazing process by brass brazing alloys have been proved and realized.

\section{Streszczenie}

Artykuł poświęcony jest analizie zjawisk na granicy podłoża ze stali odpornej na korozję z ciekłą fazą lutów na osnowie miedzi. Zjawisko pogarszania się właściwości materiału rodzimego i powstawania kruchych faz podczas lutowania stali lutami na osnowie miedzi jest dobrze znane. W ramach prowadzonych prac autorzy zbadali wpływ penetracji miedzi po granicach ziaren stali. Ponadto przedstawili możliwości lutowania stali odpornych na korozję za pomocą lutów mosiężnych.

\section{Introduction}

Sometimes in brazing and soldering practice, the negative phenomenon occurs, which consists in the base metal properties changing, which results in the product destruction or cracks appearance. In some handbooks [1] this phenomenon is referred as to the mechanical corrosion due to the melt impact. Practically, in literature there is an absence of detailed research, considering the interaction of filler metals with base material, which results in embrittlement. Probably, due to the negative experience, the brass alloys are not recommended to use for the corrosion-resistant and alloyed steel brazing. Stainless steel is brazed with brazing metals based on nickel, silver, pure copper, however, the alloys based on the copper-zinc system are not recommended for the stainless steel brazing, though they are widely used for the low-alloyed steel brazing.

Prof. Igor Pashkov, Oksana Kustova - PBSU, Moscow, Julia Vetrova - MISiS University, Moscow.
The phenomenon of the metal material embrittlement under the melts impact depends on plethora of factors, the most of which could not be expressed numerically. That is why, while the product technology design for brazing, it is easier to reject brazing with the metals, due to which the embrittlement cases have occurred, than to consider the dangerous factors and eliminate their influence. Despite the brazing process duration variety, depending on the used technology, the phenomenon of the base material properties deterioration due to brazing o soldering metal melt influence occurs at the furnace brazing, and induction, and flame one, as well.

During the recent decades, the noticeable changes took place in the brazing equipment and in the process control ability; besides, the new solder and brazing alloy compositions were designed. So, the return to research of the base metal embrittlement due to the metal melt influence for the purpose of the new trends revelation for using the materials and brazing process control may be of interest. We consider, that the research of possibility of the stainless steel brazing with brass based alloys to be the most important issue. 


\section{Mechanical properties loss under the influence of brazing or soldering melts}

\section{Decrease of metal plasticity under the influence of metal melts}

The phenomenon of strength and plasticity sharp decrease of solid bodies, which are in the contact with melts of another more fusible metals during the deformation process, has been revealed long ago. The description of this phenomenon is presented in various papers [2, 3]; however, there is no clear explanation of its reasons and implementation mechanism. That is exactly why; it is of the scientific interest nowadays too. This phenomenon was named as "liquid-metal embrittlement". It was defined, that for the fragility appearance the combined action of tensions and liquid metal was necessary. Soviet scientists, such as Rebinder, Shchukin, Likhtman, made the assumption that given phenomenon may be the particular case of vast variety of physical-chemical processes, named as "Rebinder's effect". The Rebinder's effect essence consists of changing the physical and mechanical characteristics of solid bodies under the influence of adsorption from environment. The presence of adsorption layers results in strength and hardness loss of material. The observed effects were explained by the free energy decrease of the deformed solid body. The surface tension decrease, caused by the adsorption layers formation, plays especially important role in those points, where the surface uniformity appears to be disrupted. At that, while acting even small stretching stresses, the ultramicrocracks appear, which open an access for a surface-active substance. Adsorption actively proceeds on the newly formed surfaces. In its turn, it results in involving the great amount of slip planes into deformation [9, 10]. Thus, the solid material collapses under the melt impact. Analysing the literature, where the "liquid-metal embrittlement" phenomena are described, it is possible to note two extreme cases of a solid body collapse. The first case arises during a long time within several hours and makes the catastrophic impact on durability of the material; the second case is characterized by almost instant structural failure of a solid body under the melt influence. As it has been noted above, the stretching tensions and contact with liquid melt facilitate the "liquid-metal embrittlement" phenomenon.

\section{Metal brittle failure effect while brazing}

While brazing, the brittle failure effect may be observed at short and long contact time duration of the base metal surface with the solder melt. Further, we shall not consider the influence of liquid melt on longterm strength, since while brazing the solder is located locally, and it is difficult to fancy the cases when the stretching tensions are supported at a fixed level during a long period of time. From our point of view, the thermal stresses as a result of non-uniform heating, the surface defectiveness of details before the brazing, and also the details preparation prehistory represent the most interest. The weakening and the brittle failure while brazing is accompanied first by permeation of brazing alloy melt via grain borders of the base metal. If it does not occur, then the intense brittle failure is not observed. During the melt permeation into metal, the surface energy of defects decreases. The further interaction leads to the permeation of liquid metal atoms into the crystal lattice of solid metal or to the chemical interaction between them.

The presence of impurities, oxide films, as well as residual stresses, mechanical hardening, various defects from submicroscopic up to macroscopic size at the metal surface, are of great value. Surface layer state of the base metal defines the melt impact efficiency. If the solid metal was exposed to machining, for instance, cutting, grinding, contributing the deformation development, then the melt influence intensifies.

Dependence of the embrittlement effect on the diagram type and accordingly on the interaction character of a brazed material with a brazing metal base is described in N. F. Lashko's work [4]. She notes that between the metals forming between themselves a simple eutectic with weak or nearly absent dissolution of the liquid metal in solid one, the embrittlement effect appears to the greater extent. Besides that, N. F. Lashko also notices, that propensity to embrittlement is revealed at the combination of metals, which form the peritectics between themselves also. Thus, the combination of base metal and brazing one has an influence on the liquid-metal embrittlement effect.

The temperature influence on the process of adsorptive strength loss of metals depends on physicalchemical properties of a base metal and a brazing one. While temperature rising, the influence of the melted metal platings on the solid metal increases. The tensions necessary for the melt effect development decrease along with the test temperature increase.

It is noted, that the presence of impurities in the base and melted metals also influences on the tension value. For example, the more carbon or nitrogen is in steel, the stronger the weakening effect appears at the given temperature. So, for example, the strength loss and cracks formation are observed under the influence of melted solder Cu62Zn at steels with $0.2 \mathrm{C}, 0.45 \mathrm{C}$, and stainless steel 1810. However, it is necessary to notice, that in articles generally the influence of composition and properties of solid metal is studied, and the influence of the brazing metal alloying elements is not noted practically. It is noted the possibility of brazing the corrosion-resistant steel with copper brazing alloy, which composition includes a boron and silicon, explaining this fact by the iron silicide and borides formation, which block the crack spreading on the brazed material borders. Considering this feature, the application of the boron alloyed brazing alloy Cu62ZnSn0.5Si0.2B0.04 
while the stainless steels brazing, allows to avoid the embrittlement effect.

On the basis of the available data analysis, it is possible to draw a conclusion that the embrittlement effect appearance, as well as the degree of its development, depends on the following factors:

- interaction of certain pairs "solid metal - liquid metal" forming, as a rule, the eutectic type system, with small solubility of brazing metal in a base metal;

- character of a stressed state of solid metal, more often this is the stretching tensions, internal or external;

- heating mode (induction, flame or furnace);

- presence of defects on a solid metal surface (rough edges at machining, deep scratches or section heterogeneity);

- presence of certain impurities.

However, it is necessary to notice, that on the special samples of the low-carbon steel and stainless steel, brazed by means of a flame-torch and an induction heating, the cases of liquid-metal embrittlement were not fixed unequivocally and stably. Despite the variation of heating rate and conditions of external stresses application, only the samples having defects on a surface in the form of scratch marks or deep scratches were destroyed. Therefore, in the present work authors include the description of stably received results of the base metal destruction, while brazing on the basis of real examples of brazed constructions production.

\section{Experiment implementation}

\section{Steel heat exchangers brazing in a conveyor furnace}

For the interaction exploration of brazing metal based on a pure copper, the brazing of assemblage of steel plates with cone holes, formed by deep drawing on a press (fig. 1) was implemented. As a result of strong plastic deformation of cone holes while assembling, the tensions retained at conical part of plates.

Brazing was implemented in the conveyor furnace with endogas atmosphere (35\% hydrogen) at temperature of

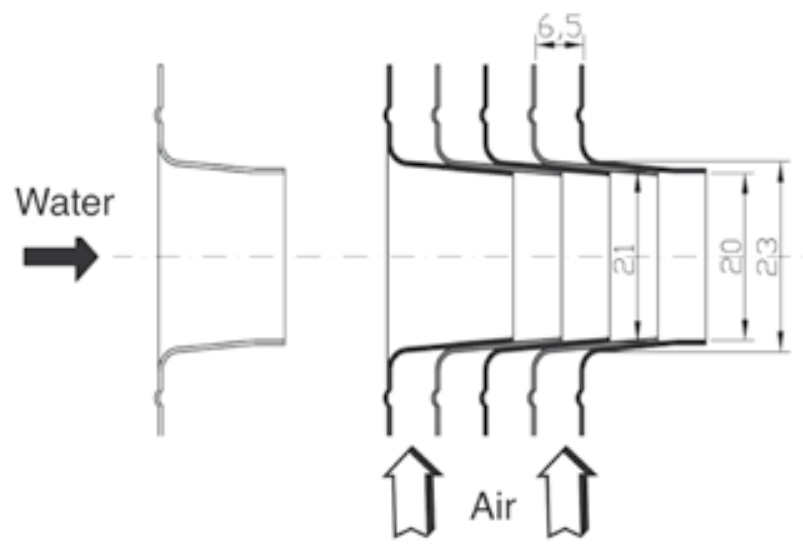

Fig. 1. Design of brazed samples for furnace brazing

Rys. 1. Przygotowanie próbek do procesu lutowania piecowego
$1130 \div 1150^{\circ} \mathrm{C}$. After in the brazed seam zone the permeation of copper melt via grain borders was revealed, the similar assemblage without brazing metal application was placed in the same furnace and was annealed in a brazing mode during 15 minutes. Then the brazing metal was applied on, and the product passed through the furnace again.

The made heat exchanger samples were cut along an axis and metallographic micro sections were made of the cut fragments, which were explored with the help of the light microscope Neofot 31.

\section{Gas-flame brazing of the refrigerator steel tubes}

The destruction phenomenon or fragility appearance of brazed seams was observed while brazing of low-alloyed steel tubes of refrigerator evaporators with brass brazing metal. Tubes were $8 \mathrm{~mm}$ diameter and have been processed on a press for the purpose of lap connection formation. For this purpose, the first tube was flared for inner diameter increase, and the second tube was exposed to the reduction of diameter on $0.2 \mathrm{~mm}$. Brazing was implemented with Cu59ZnSn3Si0.2 and Cu59ZnSn3 brazing alloys at temperature about $900^{\circ} \mathrm{C}$ with the fluoborate fluxing agent application. Samples were heated with the help of propane-oxygen torch after the preliminary fluxing of a tube surface, and when the temperature has reached about $900^{\circ} \mathrm{C}$, the brazing alloy stick of $1.6 \mathrm{~mm}$ diameter was entered.

The influence of flux, heating rate and brazing alloy composition on tubes destruction was explored. For this purpose, the tube samples were placed on a special small table for the adjustable stretching stresses creation during the brazing process (fig. 2).

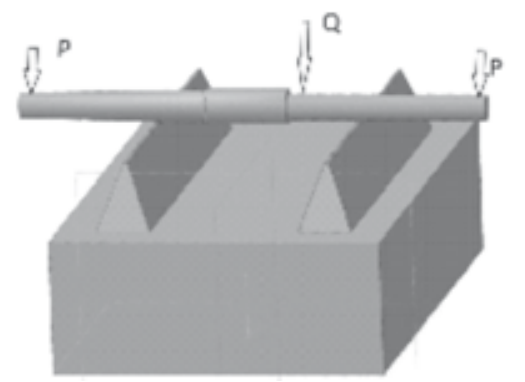

Fig. 2. Scheme of refrigerator tubes brazing

Rys. 2. Schemat procesu lutowania przewodu chłodziarki

\section{Experimental results}

\section{Penetration of copper melt via the steel grain borders while furnace brazing}

If the heating time of steel heat exchangers to brazing temperature was 10 to 12 minutes, then while brazing with copper the penetration of copper via the borders of low-carbon steel grains on depth up to $6 \div 8$ grains was observed (fig. 3a). In some places of a seam only the narrow strip of copper along steel grains border is observed, in some places the separation of grains from the base steel material and their 
placement in the seam volume is observed. The destruction of sample does not occur, however, the reduction of its thickness is observed.

Annealing of a product without brazing metal during 15 minutes at temperature about $1100^{\circ} \mathrm{C}$ results in stress relieving and the copper penetration via steel grain borders does not occur (fig. 3b).

Thus, for the first stage of the base metal properties change, namely, penetration of brazing alloy melt via grain borders, the presence of residual stresses on the steel surface, which accumulate during the process of the conic holes deep deformation, is necessary. Grain borders destruction and the brazing metal penetration via them facilitates the stressed state relieving. Probably, for the residual stress relieving the steel surface degradation in depth of several grains is enough, and there is no further change of the base metal properties. The result of the effect of preliminary annealing at high temperatures proves that the residual stresses are necessary for the melt penetration via grain borders. In the absence of tensions due to influence of annealing or usage of undistorted details, the even boundary brazing metal - base metal is observed.
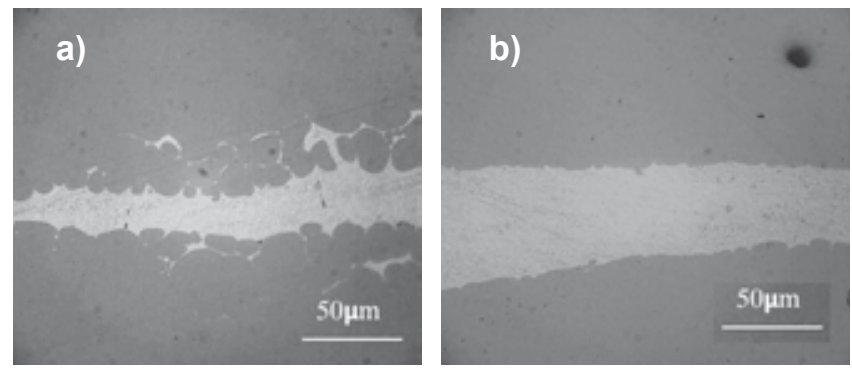

Fig. 3. Copper penetration via boundary grain: a) without annealing; b) after annealing

Rys. 3. Penetracja miedzi po granicach ziaren: a) bez wyżarzania, b) po wyżarzaniu

Thus, such a phenomenon should be considered while the brazing technology design, and the additional time should be provided for tensions relieving during the high-temperature heating till the appearance of brazing alloy liquid phase.

\section{Refrigerating unit tubes destruction while gas-flame brazing}

Destruction of low-alloyed steel tubes during the gas-flame heating always occurred at the side of reduced tube, precisely at the border of diameter change (fig. 4). No destruction occurred in other places at any changes of brazing process parameters. During the soldering process, the small load was applied to the ends of tubes (about $200 \div 300 \mathrm{~g}$ ) to start the fracture opening. As far as the destruction source is always the same - the diametrical scratch mark of the tool while reduction, then the reason of base material property change lies in a stressed state and surface defectiveness in this area.

To begin with, the conditions on samples of tubes were created in such a way, that destruction occurred

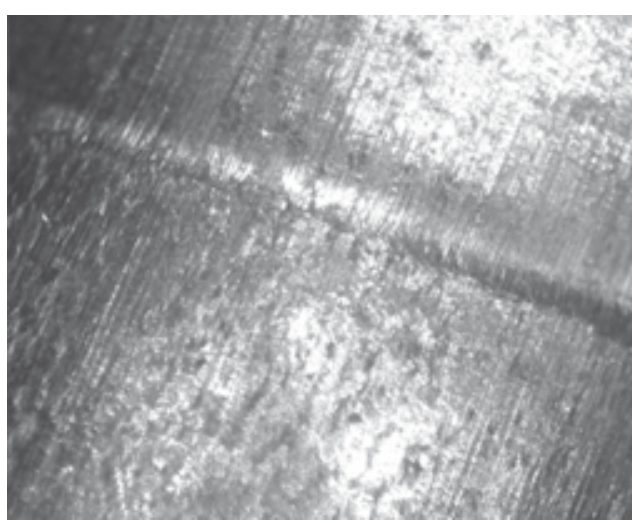

Fig. 4. Area of diameter change on a refrigeratior tube after reducing Rys. 4. Zmniejszona średnica przewodu rurowego chłodziarki

at each brazing. From the point of view of heating rate, it has been revealed, that while intensive heating with the help of propane-oxygen torch during approximately $4 \mathrm{~s}$ up to the temperature about $900^{\circ} \mathrm{C}$, the destruction occurs. At more slowly heating from $10 \mathrm{~s}$ and longer, the tensions relieving are observed in the deformed zone of a tube, and no destruction occurs while the brazing metal delivery. Thus, the fast heating in local area not only creates thermal stresses in the base metal, but also does not allow flowing the relaxation process of stresses, created while tubes preparation for brazing.

To define the flux influence, the fast heating of tubes was implemented with delivery of flux without brazing metal. Destruction of tubes along scratch marks in no one case has occurred, hence, the flux has no any influence on destruction, except it provides the brazing alloy acceptance by steel surface.

It is interesting fact, that during the local heating of one side of a tube in a brazing metal delivery zone, the destruction propagates only within zone of the liquid brazing alloy presence (fig. 5). At insufficient heating of the opposite side of a tube and the absence of brazing alloy there, the crack ceases its propagation and while its further opening the plastic deformation of tube was observed. Beyond the brazing metal spreading zone, the destruction never observed even in the presence of defect on the surface in a form of a scratch mark.

As it was already noted above, two brazing alloys differing by silicon presence in composition, have

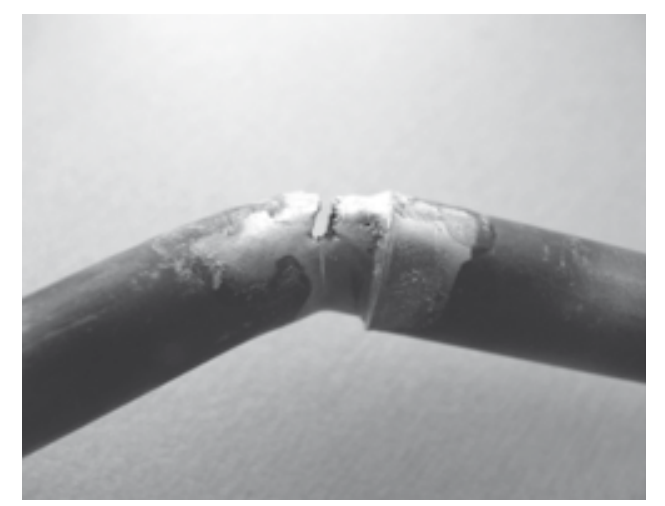

Fig. 5. Tube destruction effected by brazing alloy melt Rys. 5. Zniszczona rurka po kontakcie z ciekłym lutem 
been tested. It should be noted, that the difference was that the liquid-metal embrittlement more often have occurred with a solder, when silicon was absent in its composition. From 7 soldered joints, the destruction occurred at all samples, brazed with solder Cu59ZnSn3. While using the brazing alloy containing silicon, the destruction was observed only at 3 samples of 7 . At that, it was noticed, that for the sample destruction it is necessary to raise the brazing temperature on several tens of degrees. Hence, the alloying elements do not eliminate the liquid-metal embrittlement effect, but they expand the temperature interval where the destruction does not occur. Apparently, this fact explains the reject causes of the stainless steel brazing with brass alloys in 50-60th years of XX century, since on the basis of analysis of standards it is revealed, that small additives of silicon in a brass were not entered at that time.

Thus, the presented example of the steel tubes destruction testifies that destruction may occur with the ordinary low-carbon steel, as well. The major factors influencing on the liquid-metal embrittlement effect appearance, are the defectiveness of the joint materials surface and its stressed state. Also the heating rate and the solder composition play an important role. Research of the brazing alloy composition influence on steel destruction under the melts impact requires the separate detailed exploration, in particular, on studying the influence of alloying elements in brass brazing alloys on the possibility of the liquid-metal embrittlement of the low-alloyed and stainless steels.

\section{Conclusions}

Interaction of brazing alloy melts on a copper basis with the steel details surface, resulting in deterioration of the base metal properties may take place both while furnace brazing and while flame-torch brazing, as well. A principal cause is the presence of a stressed state or stretching tensions till the moment of the liquid brazing alloy appearance.

The liquid-metal embrittlement of low-carbon steel tubes in the presence of copper-zinc brazing metal arises due to the surface defects and tensions, which are created while tube diameter reduction.

Heating rate to high temperature provides the appearance of additional thermal stresses, which in the presence of brazing metal melt result in crack formation in a zone of initial defects, and their spreading due to the brazing alloy permeation into them. Slow heating results in stress relaxation, and the base material destruction does not occur.

The effect of influence the silicon in brazing alloy composition on the liquid-metal embrittlement appearance was revealed. Silicon additives increase the temperature interval of steel brazing with brass brazing alloy without destruction of samples.

\section{Literature}

[1] Brazing Handbook Fifth Edition, AWS, 2007.

[2] Moore R., Beckinsale S. // Journ. Inst. Metals. - 1920.
[3] Westwood A.R.C., Kamdar M.N. Concerning liquid embrittlement particularly zinc monocrystals by mercury // Philosophical Magazin. - 1963. - №89.

[4] Lashko N.F., Lashko S.V. Voprosy teorii i technologii paiky. - Saratov, 1974.

\section{PLANY SPAWANIA - TEORIA I PRAKTYKA - JACEK SŁANIA}

\section{Cena}

Cena 1 egzemplarza książki Jacka Słani:

Plany spawania - teoria i praktyka

80 zł (w tym 5\% VAT)

W celu zamówienia książki
w Redakcji należy wypełnić formularz
zamieszczony obok i przesłać go
w formie faksu, skanu lub listu na adres:

REDAKCJA - Przegląd Spawalnictwa AW SIMP

ul. Świętokrzyska 14a, 00-050 Warszawa

tel.: 2282725 42, faks: 223361479

e-mail: pspaw@ps.pl

Wpłaty należy dokonać na rachunek bankowy:

Bank BPH S.A. Oddział w Warszawie

45106000760000320000431836

\section{Zamawiam książkę Plany spawania - teoria i praktyka}

w Redakcji Przegląd Spawalnictwa w ilości .... egz.

Imię i nazwisko

Firma

Adres

NIP

Kontakt do osoby zamawiającej:

Oświadczam, że jestem podatnikiem VAT i upoważniam firmę do wystawienia faktury bez podpisu 